\title{
Fluoxetine and Norfluoxetine Revisited: New Insights into the Electrochemical and Spectroscopic Properties
}

\author{
E. Manuela Garrido, ${ }^{\dagger}$ Jorge Garrido, ${ }^{*},{ }^{\dagger}$ Rita Calheiros, ${ }^{\dagger}$ M. Paula M. Marques, ${ }^{\ddagger}$ and \\ Fernanda Borges ${ }^{\S}$ \\ UQFM/Departamento de Engenharia Química, Instituto Superior de Engenharia do Porto, 4200-072 Porto, Portugal, \\ QFM R\&D Unit, and Dep. Bioquímica, Universidade de Coimbra, Portugal, and UQFM/Departamento de Química \\ Orgânica, Faculdade de Farmácia, Universidade do Porto, 4050-047 Porto, Portugal
}

Received: May 8, 2009; Revised Manuscript Received: July 10, 2009

\begin{abstract}
The extent to which humans and wildlife are exposed to the vast array of anthropogenic chemicals and their degradation products, along with related naturally occurring compounds, is nowadays an important issue. The study of the physical-chemical properties of the compounds and/or degradation products is an important subject because some of them are intrinsically related to its resistance to degradation and/or bioaccumulation. Accordingly, the study of the electrochemical behavior of the selective serotonin reuptake inhibitor fluoxetine and its main metabolite norfluoxetine was investigated. The identification of the oxidation processes was done via two fluoxetine analogues, 1-(benzyloxy)-4-(trifluoromethyl)benzene and $N$-methyl-3-phenylpropan1 -amine hydrochloride. The oxidative processes occurring in fluoxetine are $\mathrm{pH}$-dependent and were ascribed to the chemical moieties present in the molecule: the secondary amine group and the substituted aromatic nucleus. To perform an unequivocal ascription, the structural preferences of the drug and metabolite were also determined, by Raman spectroscopy coupled to quantum mechanical calculations (at the DFT level). The analytical data obtained in this work will allow the development of a rapid and unequivocal spectroscopic procedure suitable for fluoxetine identification, as well as to distinguish between the drug and its main metabolite.
\end{abstract}

\section{Introduction}

In the past decade, fluoxetine ( $N$-methyl- $\gamma$-[4-(trifluoromethyl)phenoxy]benzene-propanamine, Scheme 1) has emerged as one of the most frequently prescribed antidepressants (marketed with diverse trade names such as Prozac) and has received a great deal of attention. Fluoxetine belongs to a group of medicines known as selective serotonin reuptake inhibitors (SSRIs) that are thought to work by increasing the activity of serotonin in the brain. Fluoxetine is commercialized as a racemic mixture whereby the $S$-enantiomer is approximately 1.5 times more potent than the $R$-enantiomer in the inhibition of serotonin reuptake. ${ }^{1}$ The conformational characteristics of the fluoxetine highly influence its neurotransmitter role and selectivity, namely the folded orientation of the [(trifluoromethyl)phenoxy] moiety relative to the amine chain. It is generally accepted that the $p$-trifluoromethyl substituent contributes either for its potency or for its selectivity, neuropharmacological action. ${ }^{2}$ This information could be connected to the lipophilicity and electronwithdrawing properties of the substituent. Fluoxetine undergoes extensive metabolic conversion, leading to an active metabolite, norfluoxetine (Scheme 1), followed in a somewhat lower proportion by conjugated or sulfate derivatives.

Recently, fluoxetine and its major metabolite have become a topic of growing public concern. These compounds have been detected in a number of environmental water samples including wastewaters effluents, rivers, and streams. ${ }^{3-5}$ Some studies have

\footnotetext{
* Corresponding author. E-mail: jjg@isep.ipp.pt.

${ }^{\dagger}$ Instituto Superior de Engenharia do Porto.

* Universidade de Coimbra.

$\S$ Universidade do Porto.
}

suggested there could be a range of potential aquatic ecosystem effects of these compounds in the environment. ${ }^{6}$ In fact, fluoxetine and norfluoxetine have been detected in fish samples obtained from an effluent-dominated stream, this information being an indicator of their bioaccumulation potential. ${ }^{7,8}$ Although bioaccumulation is usually a $\mathrm{pH}$-dependent phenomenon, ${ }^{8-10}$ little research has been addressed toward the study of the $\mathrm{pH}$ effects on pharmaceutical drugs bioaccumulation. The same concern is related to the scarce number of metabolism and toxicity studies of this type of organic micropollutants in the environment. So, this subject is nowadays considered an emergent society problem that could be minimized through an intensive investigation in the area.

Accordingly, this work emerges as a contribution to increase the knowledge of the environment fate of fluoxetine throughout the study of its metabolic oxidative pathways and a complete conformational characterization of the drug and its main metabolite, norfluoxetine (Scheme 1). Therefore, a detailed electrochemical study of fluoxetine and norfluoxetine was performed, in a broad $\mathrm{pH}$ range, using different voltammetric techniques. The identification of the oxidation processes was done by analogy-based electrochemical behavior of two synthesized fluoxetine analogues, 1-(benzyloxy)-4-(trifluoromethyl)benzene and $N$-methyl-3-phenylpropan-1-amine hydrochloride (Scheme 1). Furthermore, a thorough conformational analysis of fluoxetine and norfluoxetine was performed, by Raman spectroscopy coupled to quantum mechanical calculations (at the Density Functional Theory (DFT) level), which enabled us to obtain detailed knowledge of the structural characteristics and the vibrational behavior. 


\section{SCHEME 1: Chemical Structures of the Studied Compounds}
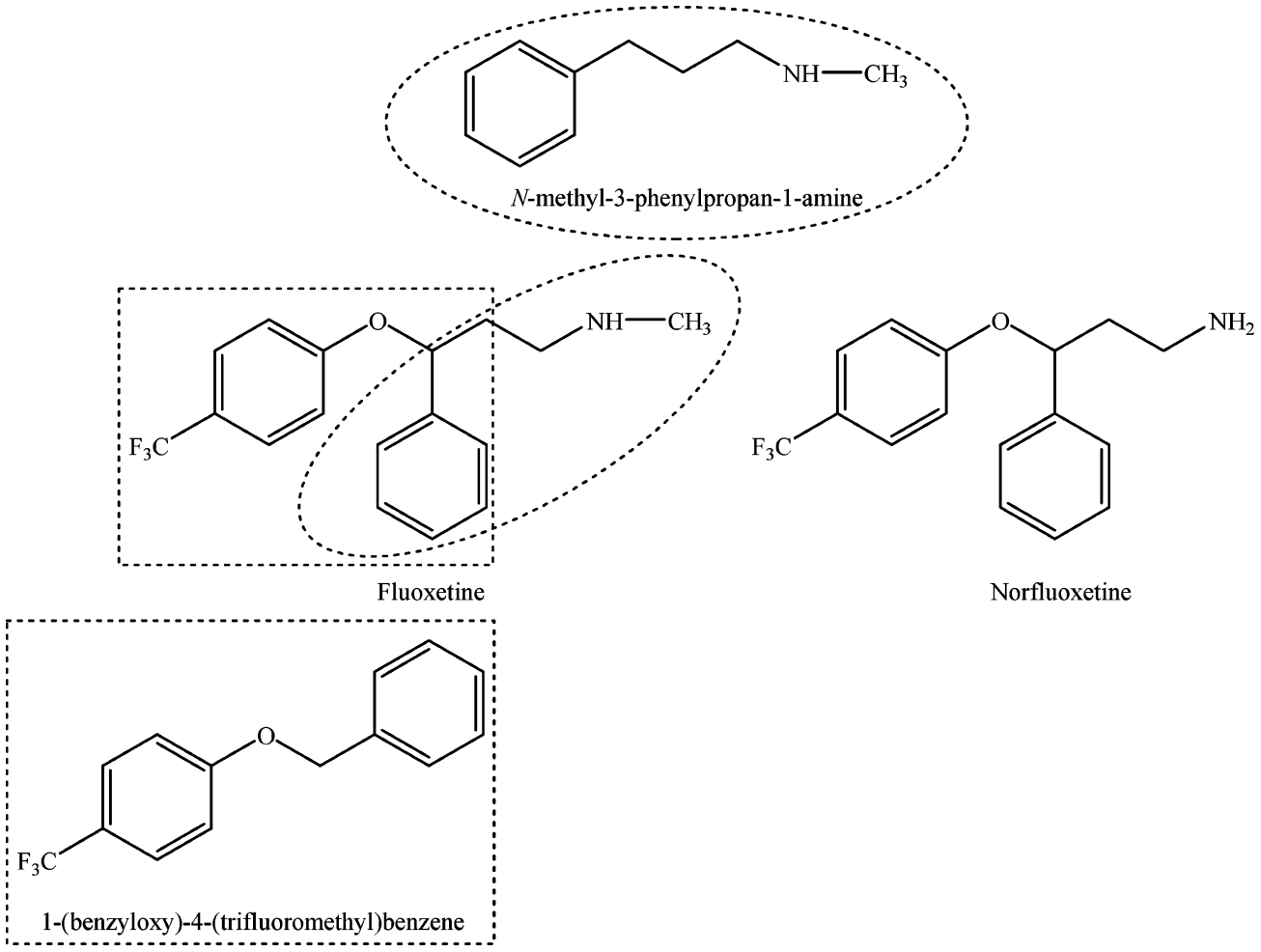

\section{Experimental Methods}

Reagents. Fluoxetine and norfluoxetine hydrochlorides were kindly provided by Lilly Farma (Lisbon, Portugal).

$\mathrm{N}$-Deuterated fluoxetine was obtained by mixing the drug with $\mathrm{D}_{2} \mathrm{O}$ (ca. $10 \%$ excess). The remaining $\mathrm{D}_{2} \mathrm{O}$ was distilled under reduced pressure. The process was repeated at least three times (until no $v_{\mathrm{NH}}$ bands were detected in the Raman spectrum).

4-(Trifluoromethyl)phenol, potassium carbonate, benzyl chloride, hydrocinnamaldehyde, methylammonium chloride, sodium cyanoborohydride, and anhydrous solvents were purchased from Sigma-Aldrich Química S.A. (Sintra, Portugal). Analytical grade reagents purchased from Merck (Darmstadt, Germany) were used without additional purification. Deionized water (conductivity $<0.1 \mu \mathrm{S} \mathrm{cm}^{-1}$ ) was used throughout the experiments. Buffer solutions employed for voltammetric determinations were $0.2 \mathrm{M}$ in the $\mathrm{pH}$ range $1.2-12.2$.

Synthesis. Structural Elucidation. ${ }^{1} \mathrm{H}$ and ${ }^{13} \mathrm{C}$ NMR data were acquired at room temperature, on a Brüker AMX 300 spectrometer operating at 300.13 and $75.47 \mathrm{MHz}$, respectively. Dimethylsulfoxide- $d_{6}$ and deuterated chloroform were used as a solvent; chemical shifts are expressed in $\delta$ (ppm) values relative to tetramethylsilane (TMS) as internal reference; coupling constants $(J)$ are given in Hz. Electron impact mass spectra (EI-MS) were carried out on a VG AutoSpec instrument; the data are reported as $\mathrm{m} / \mathrm{z}$ ( $\%$ of relative intensity of the most important fragments). Melting points were obtained on a Köfler microscope (Reichert Thermovar) and are uncorrected.

Chromatographic Conditions. The analytical control was performed by thin-layer chromatography (TLC) on plates precoated with silica gel $60 \mathrm{~F}_{254}$ as stationary phase $(0.2 \mathrm{~mm}$ as layer thickness). The spots were visualized under UV detection (254 and $366 \mathrm{~nm}$ ) and iodine vapor.

The purity of the final products ( $>98 \%$ purity) was verified using a high-performance liquid chromatography (HPLC) system equipped with UV detector. HPLC-UV chromatograms were obtained in a Jasco instrument (pumps model 880-PU and solvent mixing model 880-30, Tokyo, Japan), equipped with a Nucleosil RP-18 column ( $250 \mathrm{~mm} \times 4.6 \mathrm{~mm}, 5 \mu \mathrm{m}$, MachereyNagel, Düren, Germany), and UV detection at $230 \mathrm{~nm}$ (Jasco model 875-UV). pH 3 phosphate buffer/methanol (6:1) was used as the mobile phase, in isocratic flow rate of $1.2 \mathrm{~mL} / \mathrm{min}$. The chromatographic data were processed in a Compaq computer, fitted with CSW 1.7 software (DataApex, Czech Republic).

Synthesis of 1-(Benzyloxy)-4-(trifluoromethyl)benzene. 4-(Trifluoromethyl)phenol (1.0 g, $6.2 \mathrm{mmol})$ was dissolved in $\mathrm{N}, \mathrm{N}$ dimethylformamide (DMF) (15 mL). Potassium carbonate $(3.5$ $\mathrm{g}, 24.3 \mathrm{mmol})$ and benzyl chloride $(0.9 \mathrm{~mL}, 7.8 \mathrm{mmol})$ were then added to the solution. The resulting suspension was stirred and refluxed for $5 \mathrm{~h}$. After that the solids were filtered off and the solution was poured into ice. After acidification with $\mathrm{HCl}$ ( $\mathrm{pH} 4$ ), a white precipitate was produced. The product was filtered, washed with cold water, and identified as 1-(benzyloxy)4-(trifluoromethyl)benzene.

Yield 96\%. ${ }^{1} \mathrm{H}$ NMR (DMSO) $\delta: 5.20(2 \mathrm{H}, \mathrm{s}), 7.18(1 \mathrm{H}, \mathrm{d}$, $J=0.9), 7.21(1 \mathrm{H}, \mathrm{d}, J=0.9), 7.34-7.47(5 \mathrm{H}, \mathrm{m}), 7.64(1 \mathrm{H}$, $\mathrm{d}, J=0.9), 7.67(1 \mathrm{H}, \mathrm{d}, J=0.9) .{ }^{13} \mathrm{C} \mathrm{NMR} \delta: 69.5\left(\mathrm{CH}_{2}\right)$, $115.3(\mathrm{CH}), 126.9(\mathrm{CH}), 127.0(\mathrm{CH}), 127.8(\mathrm{CH}), 128.0(\mathrm{CH})$, $128.5(\mathrm{CH}), 136.4(\mathrm{C}), 161.2(\mathrm{C})$. EI-MS $\mathrm{m} / \mathrm{z}(\%)$ : 252, 233, 183, 161, 145, 133, 113, 91, 65.

Synthesis of N-Methyl-3-phenylpropan-1-amine Hydrochloride. Sodium cyanoborohydride $(1.2 \mathrm{~g}, 20 \mathrm{mmol})$ was added to a solution of hydrocinnamaldehyde $(2.0 \mathrm{~g}, 15 \mathrm{mmol})$ and methylammonium chloride $(10.1 \mathrm{~g}, 150 \mathrm{mmol})$ in $50 \mathrm{~mL}$ of methanol, under nitrogen atmosphere. The resulting mixture was stirred for $8 \mathrm{~h}$. Hydrochloric acid was added from time to time to keep the $\mathrm{pH}$ between 5 and 6 . After that the solution was poured into $600 \mathrm{~mL}$ of dilute hydrochloric acid. The acidic layer was then basified with $30 \%$ sodium hydroxide and extracted with dichloromethane. The organic layer was dried over $\mathrm{Na}_{2} \mathrm{SO}_{4}$, filtered, and the solvent was evaporated. The resulting oil was 
(a)

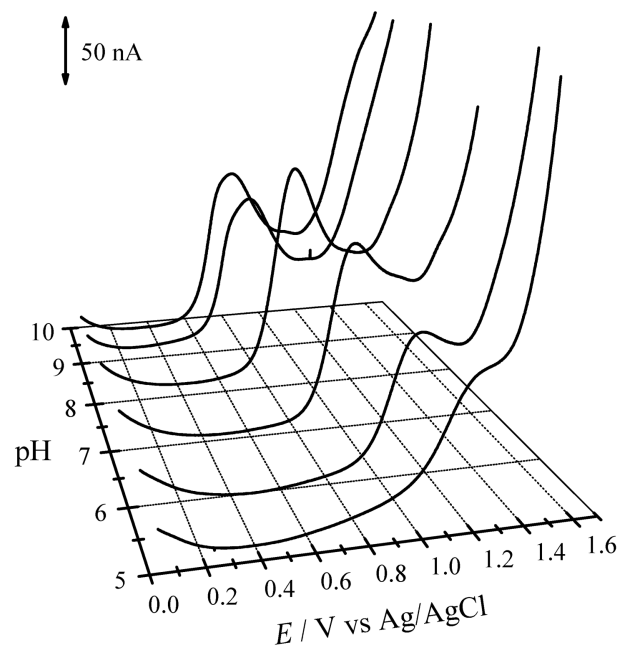

(b)

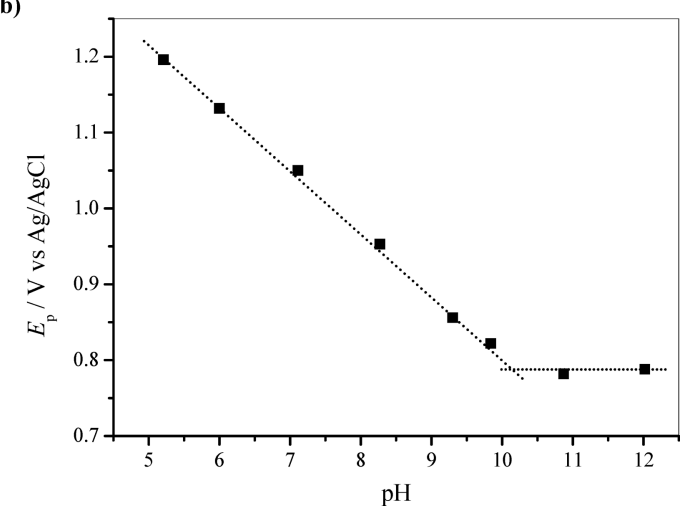

Figure 1. (a) $3 \mathrm{D}$ plot and (b) plot of $E_{\mathrm{p}} \mathrm{vs} \mathrm{pH}$ from differential pulse voltammograms of $0.2 \mathrm{mM}$ solutions of fluoxetine in different buffer electrolytes as a function of $\mathrm{pH}$. Scan rate $5 \mathrm{mV} \mathrm{s}^{-1}$.

dissolved in acidic methanol $(\mathrm{HCl})$, and diethyl ether was added until insolubilization. The white solid was filtered, washed, and identified as $N$-methyl-3-phenylpropan-1-amine hydrochloride.

Yield $40 \% .{ }^{1} \mathrm{H}$ NMR $\left(\mathrm{CDCl}_{3}\right) \delta: 1.99-2.08(2 \mathrm{H}, \mathrm{m}), 2.45$ $(3 \mathrm{H}, \mathrm{s}), 2.57-2.52(2 \mathrm{H}, \mathrm{m}), 2.76-2.70(2 \mathrm{H}, \mathrm{m}), 7.13-6.99$ $(5 \mathrm{H}, \mathrm{m}), 9.42(2 \mathrm{H}, \mathrm{brs}) .{ }^{13} \mathrm{C}$ NMR $\delta: 30.9\left(\mathrm{CH}_{2}\right), 33.2\left(\mathrm{CH}_{2}\right)$, $35.8\left(\mathrm{CH}_{3}\right), 50.9\left(\mathrm{CH}_{2}\right), 125.5(\mathrm{CH}), 128.1(\mathrm{CH}), 128.2(\mathrm{CH})$, 142.0 (C). EI-MS $m / z$. \%): 149, 134, 118, 91.

Electrochemical Studies. Voltammetric measurements were performed using an Autolab PGSTAT 12 potentiostat/galvanostat (EcoChimie, Netherlands) electrochemical analyzer. A glassy carbon working electrode (Metrohm; diameter: $2 \mathrm{~mm}$ ), an $\mathrm{Ag} / \mathrm{AgCl}$ reference electrode (Metrohm; $3 \mathrm{M} \mathrm{KCl}$ ), a glassy carbon rod counter electrode (Metrohm), and a standard onecompartment three-electrode cell were used in all experiments. The working electrode was polished manually with an aqueous slurry of alumina powder (BDH) on a microcloth pad and rinsed with water before use. All measurements were made at room temperature.

A Crison $\mathrm{pH}$-meter with glass electrode was used for the $\mathrm{pH}$ measurements (Crison, Spain).

DFT Calculations. The quantum mechanical calculations were performed using the Gaussian $03 \mathrm{~W}$ program, ${ }^{11}$ within the Density Functional Theory (DFT) approach. The widely employed hybrid method denoted by B3LYP, which includes a mixture of HF and DFT exchange terms and the gradientcorrected correlation functional of Lee, Yang and Parr, ${ }^{12,13}$ as (a)

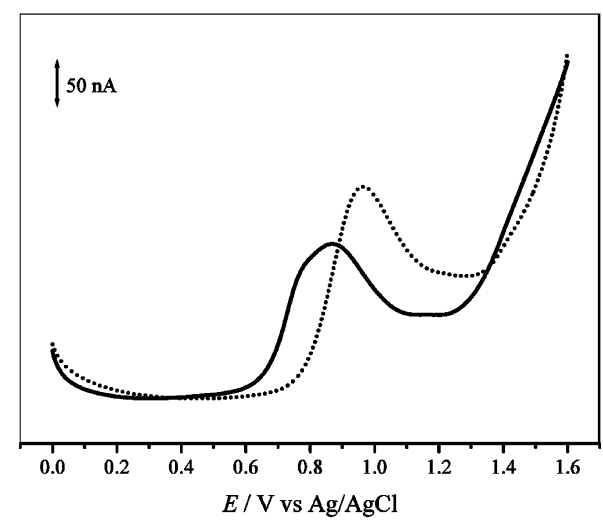

(b)

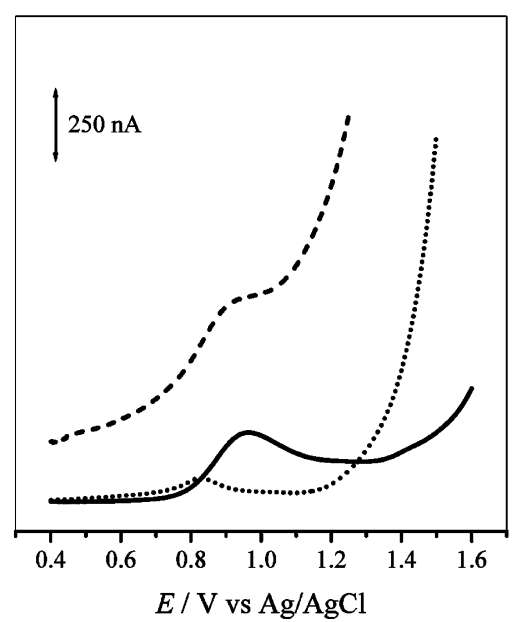

Figure 2. Differential pulse voltammograms of (a) $0.2 \mathrm{mM}$ solution of fluoxetine at ( $\cdots)$ pH 8 and (-) pH 9 buffer electrolyte and (b) $0.2 \mathrm{mM}$ solutions of (-) fluoxetine, (- - ) N-methyl-3-phenylpropan1 -amine hydrochloride, and ( $\cdots)$ 1-(benzyloxy)-4-(trifluoromethyl)benzene in $\mathrm{pH} 8$ buffer electrolyte. Scan rate $5 \mathrm{mV} \mathrm{s}^{-1}$.

\section{SCHEME 2: Proposed Mechanism for the} Electrochemical Oxidation of Fluoxetine

$$
\begin{gathered}
\mathrm{ArCH}_{3} \rightleftharpoons \mathrm{ArCH}_{3}^{\bullet+}+[\mathrm{e}] \\
2 \mathrm{ArCH}_{3}^{\bullet+} \longrightarrow \mathrm{H}_{3} \mathrm{CAr}-\mathrm{ArCH}_{3} \\
\mathrm{ArCH}_{3}^{\bullet+} \rightleftharpoons \mathrm{ArCH}_{2}^{\bullet}+\mathrm{H}^{+} \\
\mathrm{ArCH}_{2}^{\bullet} \longrightarrow[\mathrm{e}]+\mathrm{ArCH}_{2}^{+}, \text {etc. } \\
\mathrm{RNCH}_{3} \stackrel{-[\mathrm{e}],-\mathrm{H}^{+}}{+\mathrm{H}_{2} \mathrm{O}} \mathrm{RNH}_{2}+\mathrm{HCHO}
\end{gathered}
$$

proposed and parametrized by Becke, ${ }^{14,15}$ was used, along with the double- $\zeta$ split valence basis set $6-31 \mathrm{G}^{* *} .{ }^{16}$

Molecular geometries were fully optimized by the Berny algorithm, using redundant internal coordinates: ${ }^{17}$ the bond lengths to within ca. $0.1 \mathrm{pm}$ and the bond angles to within ca. $0.1^{\circ}$. The final root-mean-square (rms) gradients were always less than $3 \times 10^{-4}$ hartree bohr $^{-1}$ or hartree radian $^{-1}$. No geometrical constraints were imposed on the molecules under study.

The harmonic vibrational wavenumbers, as well as the Raman activities and infrared intensities, were calculated at the same level of theory, yielding the corresponding calculated vibrational pattern. Frequencies above $400 \mathrm{~cm}^{-1}$ were scaled by a factor of $0.9614^{18}$ before comparing them with the experimental data, to correct for the anharmonicity of the experimental normal modes of vibration. 
(a)

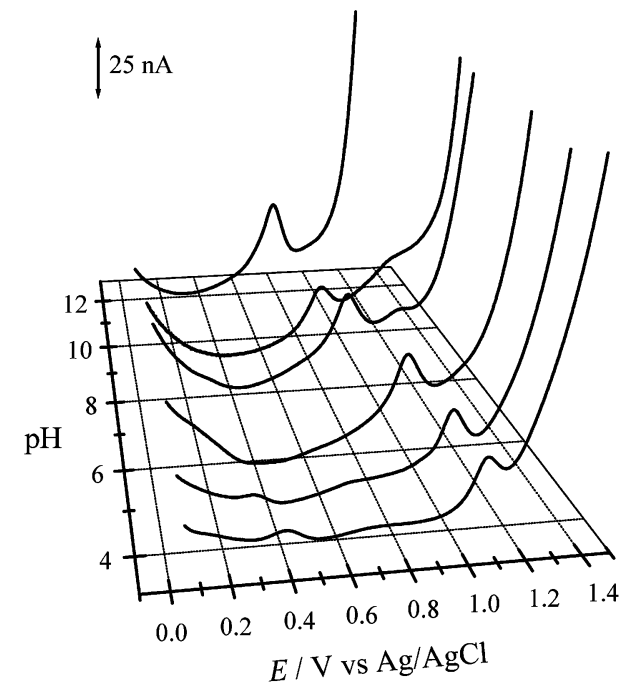

(b)

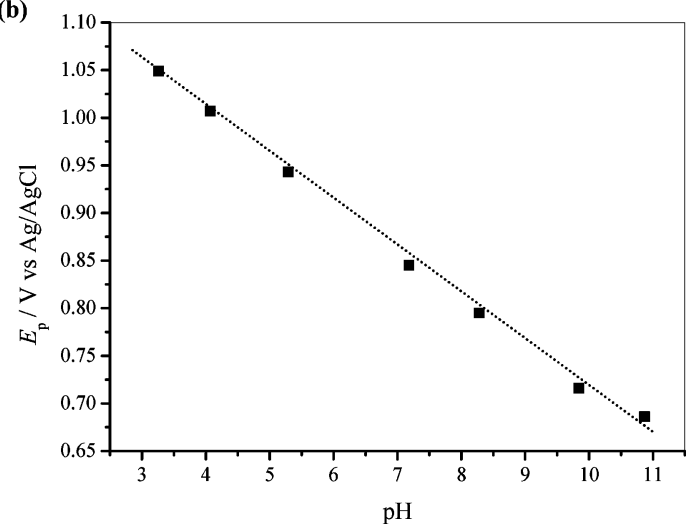

Figure 3. (a) $3 \mathrm{D}$ plot and (b) plot of $E_{\mathrm{p}} \mathrm{vs} \mathrm{pH}$ from differential pulse voltammograms of $0.2 \mathrm{mM}$ solutions of 1-(benzyloxy)-4-(trifluoromethyl)benzene in different buffer electrolytes as a function of $\mathrm{pH}$. Scan rate $5 \mathrm{mV} \mathrm{s}^{-1}$.

Raman Spectroscopy. The Raman spectra were collected for the solid compounds, at room temperature, on a triple monochromator Jobin-Yvon T64000 Raman system (focal distance $0.640 \mathrm{~m}$, aperture $f / 7.5$ ) equipped with holographic gratings of 1800 grooves $\mathrm{mm}^{-1}$. The premonochromator stage was used in the subtractive mode. The detection system was a liquid nitrogen cooled nonintensified $578 \times 385$ pixel (1/2”) charge coupled device (CCD) chip. A Coherent (model Innova 300-05 $\mathrm{Ar}^{+}$laser was used as light source, the output of which at $514.5 \mathrm{~nm}$ was adjusted to provide $90 \mathrm{~mW}$ at the sample position. A $90^{\circ}$ geometry, between the incident radiation and the collecting system, was employed. The entrance slit was set to $200 \mu \mathrm{m}$, and the slit between the premonochromator and the spectrograph was opened to $12 \mathrm{~mm}$. An integration time of $5 \mathrm{~s}$ and 30-50 scans were used in all experiments. Samples were sealed in Kimax glass capillary tubes of $0.8 \mathrm{~mm}$ inner diameter. Under the above-mentioned conditions, the error in wavenumbers was estimated to be within $1 \mathrm{~cm}^{-1}$.

\section{Results and Discussion}

Chemistry. Different synthetic strategies were used to obtain 1-(benzyloxy)-4-(trifluoromethyl)benzene and $N$-methyl-3-phenylpropan-1-amine hydrochloride. The first model compound was obtained by an $O$-benzylation reaction of 4-(trifluoromethyl)phenol in basic medium. ${ }^{19}$ As the other model compound is functionally a methyl amine derivative, it was believed that (a)

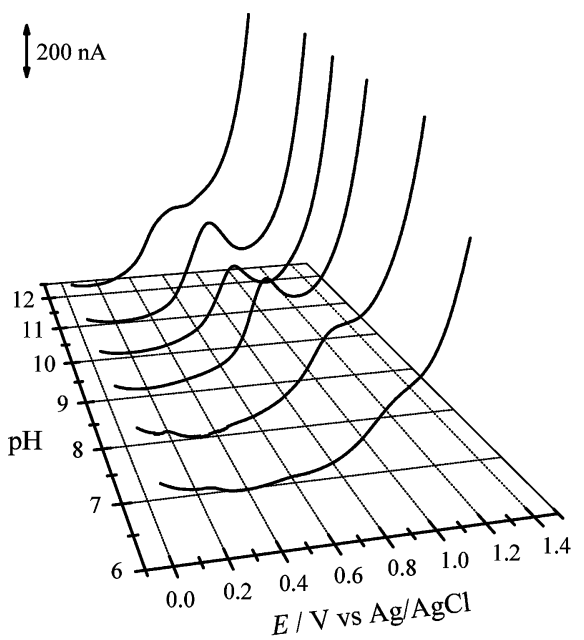

(b)

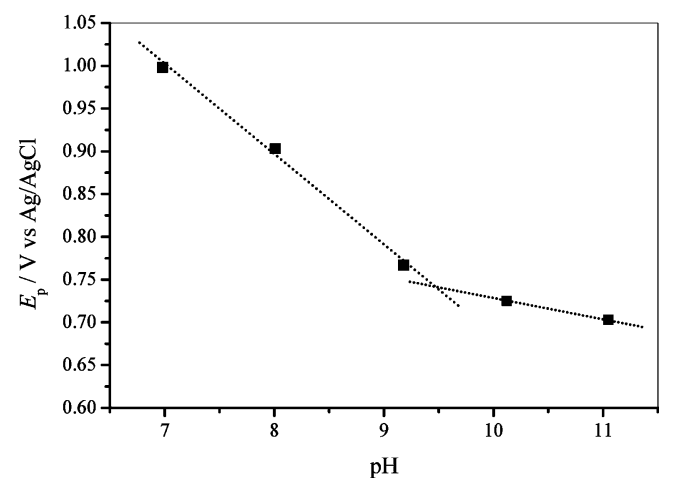

Figure 4. (a) $3 \mathrm{D}$ plot and (b) plot of $E_{\mathrm{p}} \mathrm{vs} \mathrm{pH}$ from differential pulse voltammograms of $0.2 \mathrm{mM}$ solutions of $N$-methyl-3-phenylpropan-1amine hydrochloride in different buffer electrolytes as a function of pH. Scan rate $5 \mathrm{mV} \mathrm{s}^{-1}$.

the suitable synthetic strategy could be related to the obtention of a precursor with a primary amine function that could be subsequently $N$-alkylated. However, the $N$-alkylation of a primary amine is frequently regarded as a slow and unclean process that results in a mixture of the secondary and tertiary amines as side compounds. Because of the mentioned synthetic difficulties, an indirect alkylation process was chosen to obtain $\mathrm{N}$-methyl-3-phenylpropan-1-amine hydrochloride. The method seemed to be an attractive approach because it corresponds to a one-pot reaction in which an aldehyde (hydrocinnamaldehyde) is treated with methylammonium chloride in the presence of sodium cyanoborohydride. In fact, the reductive amination of the carbonyl function led to the pretended compound in an excellent yield. ${ }^{20,21}$ The structural elucidation of the compounds was performed by FT-IR, NMR, and EM and is presented in the Experimental Methods.

Electrochemical Studies. To understand fluoxetine oxidation pathways and to assess the influence of $\mathrm{pH}$ on its oxidative and degradation profile, a comprehensive study on the electrochemical properties of this molecule was therefore carried out, in a broad $\mathrm{pH}$ range (1.2-12.2), at a glassy carbon electrode, using different voltammetric techniques.

The differential pulse voltammetric (DPV) behavior of fluoxetine yielded one anodic wave, $E_{\mathrm{p}}=+1.20 \mathrm{~V}$, starting at $\mathrm{pH} 5$ (Figure 1a). As the $\mathrm{pH}$ increased, the anodic wave observed starting at $\mathrm{pH} 9, E_{\mathrm{p}}=+0.86 \mathrm{~V}$, appears to be the result of the sum of two close peaks (Figure 1a). In fact, a welldefined shoulder prior to the main peak is observed, meaning 

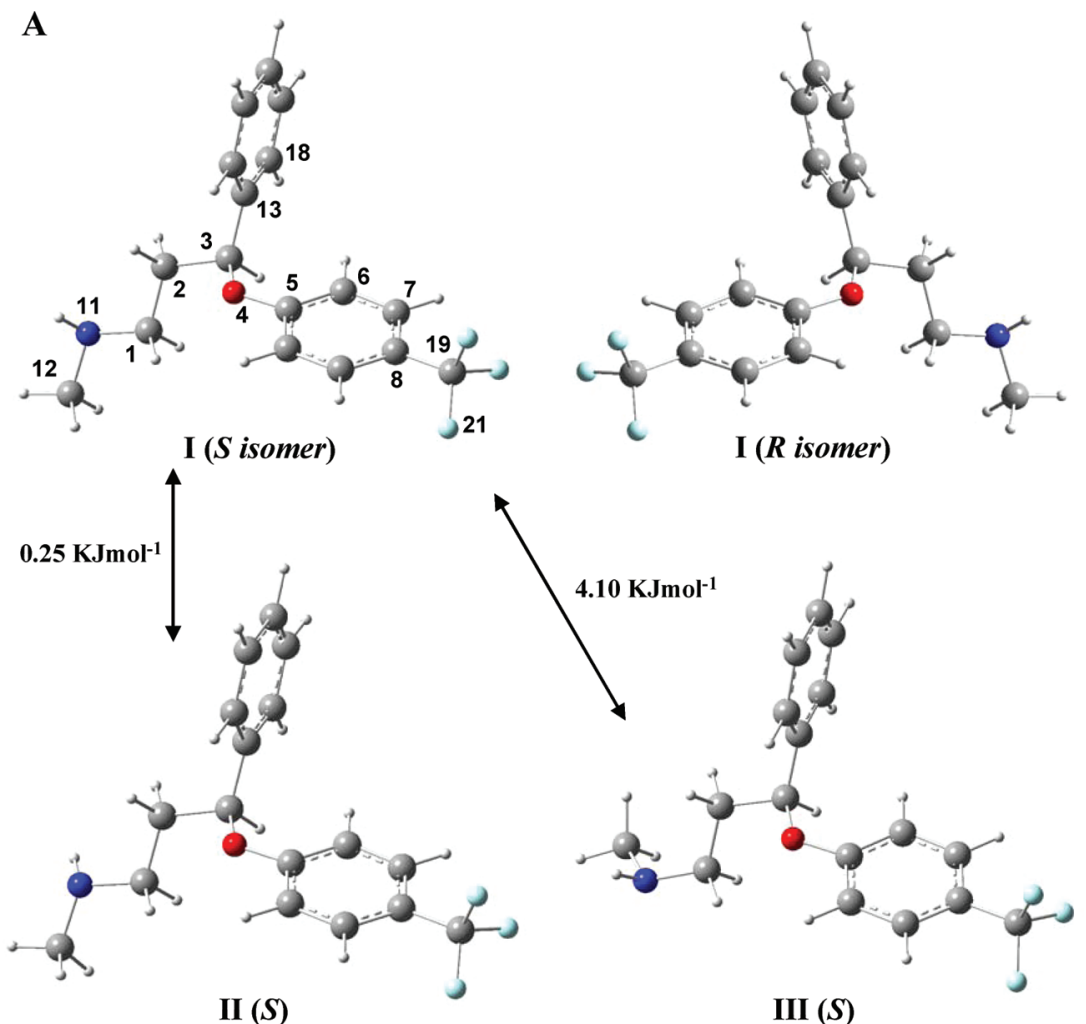

III (S)

B

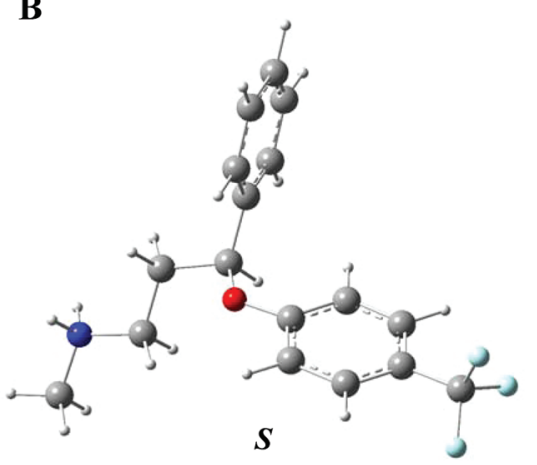

C

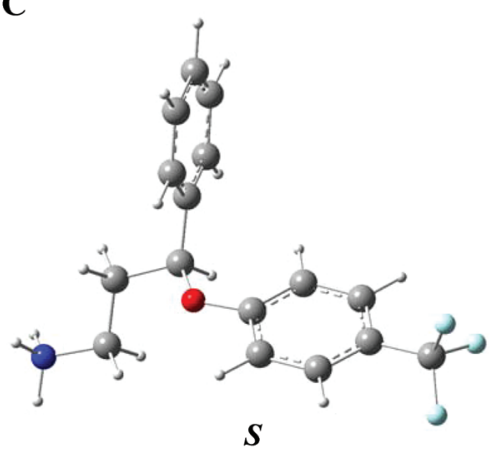

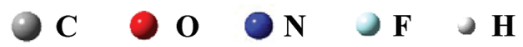

Figure 5. Schematic representation of the most stable conformers calculated for fluoxetine (A), N-protonated fluoxetine (B), and N-protonated norfluoxetine (C) (B3LYP/6-31G** level of calculation; the atom numbering for fluoxetine is included, according to that previously used in X-ray studies of the molecule $\left.{ }^{31}\right)$.

that the two peaks are almost superimposed (Figure 2a). On the basis of the literature and author's electrochemical expertise on this type of compounds, it was assumed that the main oxidative process, starting at $\mathrm{pH} 5$, occurs due to the existence of a secondary amine group, and the second oxidation signal is a result of an oxidation occurring on the aromatic nucleus that bears the $p$-trifluoromethyl substituent (Schemes 1 and 2).22,23 The peak potential $\left(E_{\mathrm{p}}\right)$ of the oxidation process moved to less positive potential when raising the $\mathrm{pH}$ (Figure 1b). At $\mathrm{pH}$ higher than 10 , the electrode process is $\mathrm{pH}$-independent. The interception point observed at $\mathrm{pH} 10$ can be attributed to the ionization constant of fluoxetine. This is in accordance with the $\mathrm{p} K_{\mathrm{a}}$ described in the literature $\left(\mathrm{p} K_{\mathrm{a}}=10.1^{8}\right)$.

To better comprehend the oxidative profile and to establish an unequivocal identification of the oxidation processes occurring, the voltammetric assessment was extended to the study of two fluoxetine analogues, 1-(benzyloxy)-4-(trifluoromethyl)- benzene and $N$-methyl-3-phenylpropan-1-amine hydrochloride (Scheme 1), obtained by analogy-based synthetic design.

Excluding the peak observed at $+0.35 \mathrm{~V}$ for $\mathrm{pH} 3-4$, which is related to the GCE background current, the DPV behavior of 1-(benzyloxy)-4-(trifluoromethyl)benzene yielded a single anodic wave, $E_{\mathrm{p}}=+1.05 \mathrm{~V}$, starting at $\mathrm{pH} 3$ (Figure 3a). The peak potential $\left(E_{\mathrm{p}}\right)$ is $\mathrm{pH}$-dependent, because a decrease was observed upon $\mathrm{pH}$ increment (Figure 3b). At $\mathrm{pH} 7$ and 8, a second poorly resolved wave is seen at $E_{\mathrm{p}}=+1.40 \mathrm{~V}$. Considering the molecular structure, it is reasonable to assume that the main oxidation peak observed could only be ascribed to the unique function present in the molecule susceptible to be oxidized, the oxygen aromatic ether. Previous work on similar alkoxybenzenes and literature data indicated that the oxidation process proceeds at the aromatic nucleus, through a one-electron transfer, via the formation of an unstable cation-radical intermediate that could undergo further subsequent reactions. ${ }^{24-27}$ 


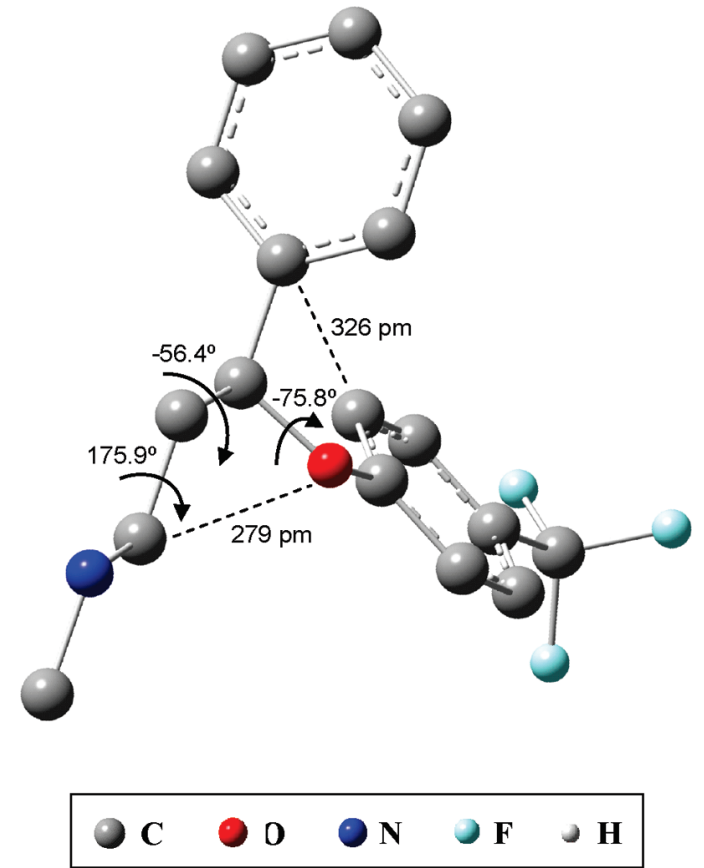

Figure 6. Representation of the most stable conformer calculated for fluoxetine showing the quasi-perpendicular position of the two aromatic rings (B3LYP/6-31G** level of calculation).

The second poorly resolved wave observed at $\mathrm{pH} 7$ and 8, not detected for fluoxetine, must then be related to the oxidation of the species resulting from the formation and dimerization of the initial cation radical (Scheme 2). ${ }^{25,27}$ As this moiety is present in fluoxetine (Scheme 1), it seems reasonable to infer that the pharmaceutical drug shares the same oxidation pattern. Moreover, the results observed for this analogue, and in particular the evidence of the formation of dimeric species, could contribute to explain the strong adsorption processes that occur when using glassy carbon electrodes for measuring fluoxetine, which is perhaps the main reason for the limited use of electrochemical methods for its quantification. ${ }^{28,29}$

The DPV study of the other model compound $N$-methyl-3phenylpropan-1-amine hydrochloride yielded an anodic wave, $E_{\mathrm{p}}=+1.00 \mathrm{~V}$, starting at $\mathrm{pH} 7$ (Figure 4a). The aliphatic secondary amine present in the molecule structure must be responsible for the oxidative behavior found for this compound. Actually, other aliphatic amines described in the literature disclose a similar oxidation peak at this $E_{\mathrm{p}}$ value. ${ }^{22,30}$ The peak potential $\left(E_{\mathrm{p}}\right)-\mathrm{pH}$ plot of this $N$-methylamine (Figure $4 \mathrm{~b}$ ) shows two linear segments, indicating that the electrode process is $\mathrm{pH}-$ dependent. The break in the $E_{\mathrm{p}}-\mathrm{pH}$ plot can be ascribed to the changes in protonation of the amine group present in the molecule. From the intersection point, it is possible to deduce the $\mathrm{N}$-methyl-3-phenylpropan-1-amine hydrochloride voltammetric ionization constant $\left(\mathrm{p} K_{\mathrm{a}}\right)$ value as 9.4. This result reinforces the previous statements performed on fluoxetine oxidation peak identification because it is in accordance with the described $\mathrm{p} K_{\mathrm{a}}$ value of the drug. Hence, it is valid to assume that the main oxidative process occurring in fluoxetine is related to the oxidation of the secondary amine group present in the molecule structure (Scheme 2). The appearance of the welldefined shoulder prior to the main oxidation peak in fluoxetine is probably related to an oxidation step occurring at the substituted aromatic nucleus yielding an unstable cation-radical that could undergo further subsequent reactions such as dimerization (Scheme 2). Comparing the voltammetric behavior observed for the model compounds at $\mathrm{pH} 8$ (Figure 2b), it is
TABLE 1: Main Geometrical Parameters Presently Calculated for Base (Fluox) and Salt (Fluox $\cdot \mathbf{H C l}$ ) Forms of Fluoxetine (Isomer $S$ ) and Comparison with $\mathrm{X}$-ray Reported Values for Fluoxetine Hydrochloride

\begin{tabular}{|c|c|c|c|}
\hline & calculated $^{a}$ & & \\
\hline & Fluox $(S)$ & Fluox $\cdot \mathrm{HCl}(S)$ & Fluox $\cdot \mathrm{HCl}$ \\
\hline$\mu(\mathrm{D})^{c}$ & 3.3 & 23.6 & \\
\hline $\begin{array}{l}\text { Bond Lengths /pm } \\
\mathrm{C}_{1}-\mathrm{N}_{11}^{d} \\
\mathrm{C}_{1}-\mathrm{C}_{2} \\
\mathrm{C}_{3}-\mathrm{O}_{4} \\
\mathrm{O}_{4}-\mathrm{C}_{5} \\
\mathrm{C}_{5}-\mathrm{C}_{6} \\
\mathrm{C}_{3}-\mathrm{C}_{13} \\
\mathrm{~N}_{11}-\mathrm{H} \\
\mathrm{C}_{1}-\mathrm{H} \\
\mathrm{C}_{6}-\mathrm{H} \\
\mathrm{C}_{8}-\mathrm{C}_{19} \\
\mathrm{C}_{19}-\mathrm{F}_{21} \\
\mathrm{C}_{6}-\mathrm{C}_{18} \\
\mathrm{H}_{3}-\mathrm{H}_{6} \\
\mathrm{H}_{6}-\mathrm{H}_{18}\end{array}$ & $\begin{array}{l}145.8 \\
153.0 \\
143.9 \\
136.4 \\
140.4 \\
152.1 \\
101.8 \\
109.6 \\
108.5 \\
150.0 \\
135.4 \\
392.5 \\
222.6 \\
312.6\end{array}$ & $\begin{array}{l}152.1 \\
152.5 \\
142.8 \\
138.3 \\
140.0 \\
151.9 \\
102.6 \\
109.1 \\
108.5 \\
150.6 \\
135.1 \\
392.7 \\
224.2 \\
309.9\end{array}$ & $\begin{array}{l}228.0 \\
281.1\end{array}$ \\
\hline $\begin{array}{l}\text { Bond Angles /deg } \\
\mathrm{C}_{12}-\mathrm{N}_{11}-\mathrm{C}_{1} \\
\mathrm{~N}_{11}-\mathrm{C}_{1}-\mathrm{C}_{2} \\
\mathrm{C}_{1}-\mathrm{C}_{2}-\mathrm{C}_{3} \\
\mathrm{C}_{2}-\mathrm{C}_{3}-\mathrm{O}_{4} \\
\mathrm{C}_{3}-\mathrm{O}_{4}-\mathrm{C}_{5} \\
\mathrm{O}_{4}-\mathrm{C}_{5}-\mathrm{C}_{6} \\
\mathrm{C}_{5}-\mathrm{C}_{6}-\mathrm{C}_{7} \\
\mathrm{C}_{13}-\mathrm{C}_{3}-\mathrm{O}_{4} \\
\mathrm{C}_{8}-\mathrm{C}_{19}-\mathrm{F}_{21}\end{array}$ & $\begin{array}{l}113.2 \\
110.7 \\
113.7 \\
105.8 \\
120.2 \\
115.2 \\
120.2 \\
112.3 \\
111.8\end{array}$ & $\begin{array}{l}114.8 \\
111.1 \\
111.3 \\
104.3 \\
119.9 \\
115.0 \\
119.8 \\
114.0 \\
111.4\end{array}$ & \\
\hline $\begin{array}{l}\text { Dihedral Angles /deg } \\
\mathrm{C}_{12}-\mathrm{N}_{11}-\mathrm{C}_{1}-\mathrm{C}_{2} \\
\mathrm{~N}_{11}-\mathrm{C}_{1}-\mathrm{C}_{2}-\mathrm{C}_{3} \\
\mathrm{C}_{1}-\mathrm{C}_{2}-\mathrm{C}_{3}-\mathrm{C}_{13} \\
\mathrm{C}_{1}-\mathrm{C}_{2}-\mathrm{C}_{3}-\mathrm{O}_{4} \\
\mathrm{C}_{13}-\mathrm{C}_{3}-\mathrm{O}_{4}-\mathrm{C}_{5} \\
\mathrm{C}_{3}-\mathrm{O}_{4}-\mathrm{C}_{5}-\mathrm{C}_{6} \\
\mathrm{O}_{4}-\mathrm{C}_{5}-\mathrm{C}_{6}-\mathrm{C}_{7} \\
\mathrm{C}_{7}-\mathrm{C}_{8}-\mathrm{C}_{19}-\mathrm{F}_{21} \\
\mathrm{H}-\mathrm{C}_{3}-\mathrm{C}_{2}-\mathrm{C}_{1} \\
\mathrm{H}-\mathrm{C}_{3}-\mathrm{C}_{13}-\mathrm{C}_{18}\end{array}$ & $\begin{array}{r}179.9 \\
-176.0 \\
174.3 \\
-63.1 \\
-77.7 \\
7.4 \\
179.4 \\
37.5 \\
53.5 \\
30.0\end{array}$ & $\begin{array}{r}-179.4 \\
175.9 \\
-179.4 \\
-56.4 \\
-75.8 \\
4.4 \\
178.9 \\
36.7 \\
60.3 \\
27.0\end{array}$ & $\begin{array}{r}60.6 \\
75.8 \\
-14.5\end{array}$ \\
\hline
\end{tabular}

${ }^{a}$ At the B3LYP/6-31G** level; the values for the unprotonated species refer to the most stable conformer (I). ${ }^{b}$ From ref 31. ${ }^{c}$ Dipole moment, in debyes; $1 \mathrm{D}=1 / 3 \times 10^{-2} \mathrm{Cm} .{ }^{d}$ Atoms are numbered according to Figure 5A.

possible to verify a close match between the oxidative signals obtained for fluoxetine and $N$-methyl-3-phenylpropan-1-amine hydrochloride. The wave observed for 1-(benzyloxy)-4-(trifluoromethyl)benzene is also consistent in terms of peak potential, $E_{\mathrm{p}}$, and peak current, $I_{\mathrm{p}}$, with the anodic shoulder verified for fluoxetine (Figure $2 b$ ).

The peak potential versus $\mathrm{pH}$ data of fluoxetine cyclic voltammetry studies reinforce the data acquired by DPV. Cyclic voltammetric experiments showed the irreversible nature of the oxidation process, because no reduction wave was observed on the cathodic branch. On increasing the scan rate, the peak potential shifted to more positive values, a fact that confirms the irreversible nature of the oxidation process.

The oxidative profile of the main metabolite norfluoxetine (Scheme 1) was assessed by DPV. Unexpectedly, any noteworthy oxidative peak was observed over the entire $\mathrm{pH}$ range and potential window studied. Considering the molecular structure similarities between fluoxetine and norfluoxetine (Scheme 1) and the previous assumptions, a comparable oxidative pattern would be expected. 


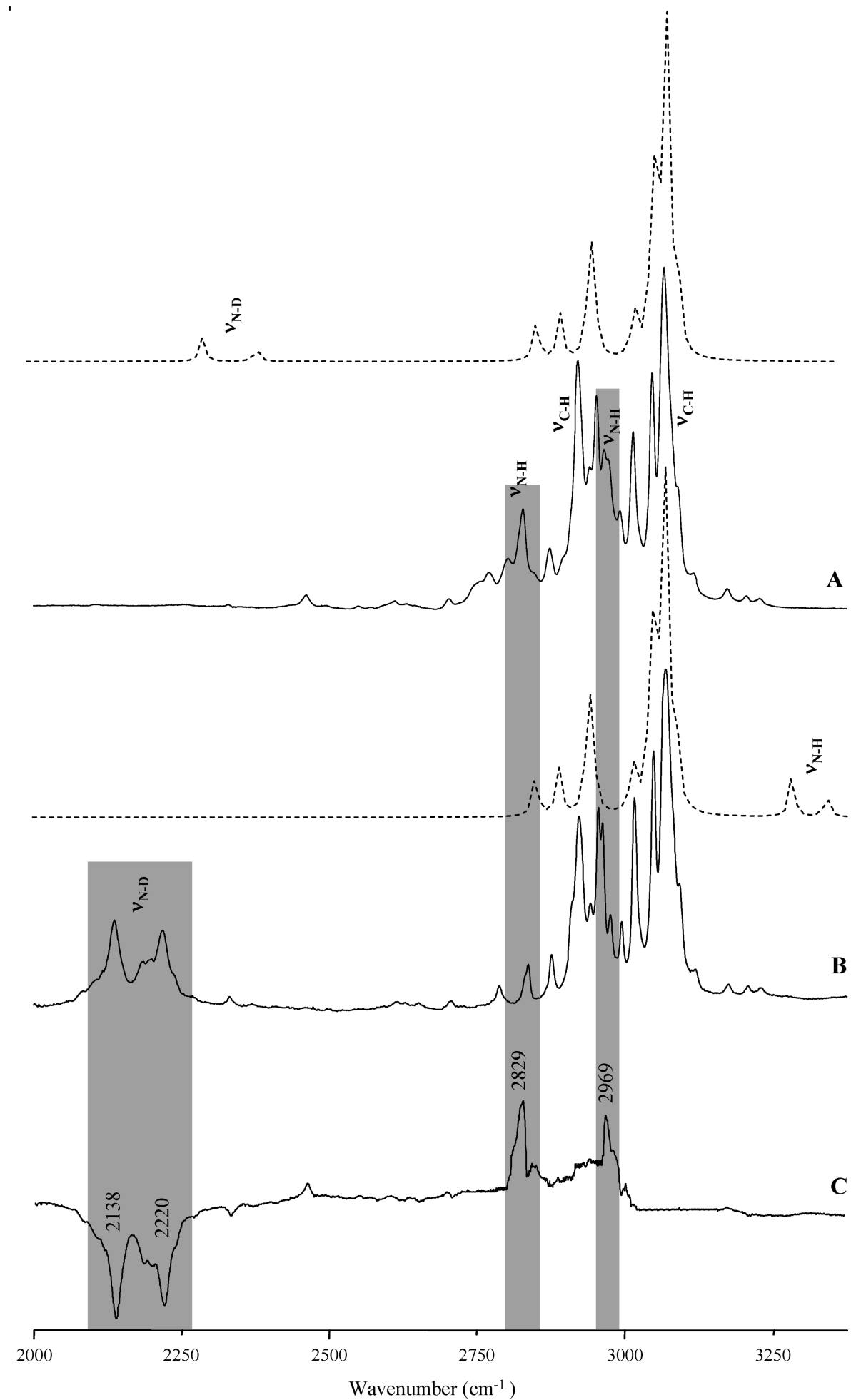

Figure 7. Experimental Raman spectra $\left(2000-3375 \mathrm{~cm}^{-1}\right.$, solid state, $\left.25^{\circ} \mathrm{C}\right)$ for protonated fluoxetine (A), protonated fluoxetine- $\mathrm{Nd}_{1}(\mathrm{~B})$, and $(\mathrm{A}$ $-\mathrm{B}$ ) difference spectrum $(\mathrm{C})$.

To justify the apparent anodic inactivity of norfluoxetine, a plausible explanation is herein outlined. In fact, in view of the peak currents observed for 1-(benzyloxy)-4-(trifluoromethyl)benzene (Figures $2 \mathrm{~b}$ and $3 \mathrm{a}$ ), it is expected that the norfluoxetine oxidation process could also lead to a small magnitude wave. As the oxidative signal is dependent on the kinetics of electron transfer and diffusion coefficient of the species, the decrease of the peak height could derive in a loss of sensitivity and resolution. So, a low signal to background (S/B) ratio can result that could be regarded as the absence of electroactivity. On the other hand, norfluoxetine possesses in its molecular structure an electroactive aliphatic primary amine. However, as primary amines usually oxidize at potentials higher than that allowed by the potential window of glassy carbon electrodes, the amine oxidation signal could not be observed.

To rationalize the apparent discrepancy of fluoxetine and norfluoxetine results, a complete conformational study of the drug and its metabolite was performed.

Conformational Analysis. The first step of these studies was related to the conformational analysis of each fluoxetine 
TABLE 2: Experimental (Solid State, $25^{\circ} \mathrm{C}$ ) and Calculated Raman Wavenumbers $\left(\mathrm{cm}^{-1}\right)$ for Protonated Fluoxetine $($ Fluox) and N-Deuterated Protonated Fluoxetine (Fluox-N-d)

\begin{tabular}{|c|c|c|c|c|}
\hline \multicolumn{2}{|c|}{ experimental $^{a}$} & \multicolumn{2}{|c|}{ calculated $^{b}$} & \multirow[b]{2}{*}{ approximate description ${ }^{c}$} \\
\hline Fluox & Fluox-N-d & Fluox $(S)$ & Fluox $(S)-\mathrm{N}-\mathrm{d}$ & \\
\hline 3066 & 3069 & $3112(3 ; 99)$ & $3112(3 ; 99)$ & $v_{\mathrm{S}}(\mathrm{CH})_{\text {ring1 }}$ \\
\hline 3014 & 3016 & $3097(2 ; 59)$ & $3097(2 ; 59)$ & $v_{\text {as }}(\mathrm{CH})_{\text {ring1 }}$ \\
\hline 2992 & 2994 & $3094(8 ; 281)$ & $3094(8 ; 281)$ & $v_{\mathrm{s}}(\mathrm{CH})_{\text {ring } 2}$ \\
\hline 2969 & & $3343(59 ; 29)$ & & $v_{\mathrm{as}}(\mathrm{NH})$ \\
\hline 2965 & 2963 & $3085(12 ; 39)$ & $3083(5 ; 51)$ & $v_{\text {as }}(\mathrm{CH})_{\text {ring1 }}$ \\
\hline 2920 & 2922 & $3050(1 ; 22)$ & $3050(1 ; 20)$ & $v_{\mathrm{as}}\left(\mathrm{CH}_{2}\right)$ \\
\hline 2873 & 2907 & $2976(0 ; 65)$ & $2976(0 ; 63)$ & $v_{\mathrm{s}}\left(\mathrm{CH}_{3}\right)$ \\
\hline 2847 & 2876 & $2932(10 ; 59)$ & $2931(10 ; 58)$ & $v_{\mathrm{s}}\left(\mathrm{CH}_{2}\right)$ \\
\hline 2832 & 2836 & $2896(19 ; 52)$ & $2896(19 ; 52)$ & $v(\mathrm{CH})$ \\
\hline 2829 & & $3290(38 ; 53)$ & & $v_{\mathrm{s}}(\mathrm{NH})$ \\
\hline 2827 & 2830 & & & $v_{\mathrm{s}}\left(\mathrm{CH}_{3}\right)$ \\
\hline 1603 & & $1604(39 ; 7)$ & & sciss. $\left(\mathrm{NH}_{2}\right)$ \\
\hline 1605 & 1606 & $1595(0 ; 37)$ & $1595(0 ; 37)$ & $v(\mathrm{C}=\mathrm{C})_{\text {ring2 }}$ \\
\hline 1587 & 1589 & $1579(21 ; 10)$ & $1579(22 ; 10)$ & $v(\mathrm{C}=\mathrm{C})_{\text {ring }}$ \\
\hline 1471 & 1465 & $1463(14 ; 13)$ & $1462(13 ; 12)$ & $\delta_{\text {as }}\left(\mathrm{CH}_{3}\right)+$ sciss. $\left(\mathrm{CH}_{2}\right)$ \\
\hline 1455 & 1458 & $1449(23 ; 13)$ & $1448(12 ; 10)$ & $\delta_{\text {as }}\left(\mathrm{CH}_{3}\right)+$ sciss. $\left(\mathrm{CH}_{2}\right)$ \\
\hline 1430 & 1431 & $1434(9 ; 11)$ & $1446(22 ; 14)$ & $\delta_{\text {as }}\left(\mathrm{CH}_{3}\right)+$ sciss. $\left(\mathrm{CH}_{2}\right)$ \\
\hline 1393 & 1403 & $1411(3 ; 2)$ & $1410(2 ; 2)$ & $\delta_{\mathrm{s}}\left(\mathrm{CH}_{3}\right)$ \\
\hline 1359 & 1362 & $1350(14 ; 12)$ & $1350(18 ; 11)$ & $\omega\left(\mathrm{CH}_{2}\right)+\gamma(\mathrm{CH})$ \\
\hline 1326 & 1327 & $1319(44 ; 16)$ & $1329(15 ; 19)$ & $\omega\left(\mathrm{CH}_{2}\right)+\gamma(\mathrm{CH})$ \\
\hline 1313 & 1317 & $1308(27 ; 11)$ & $1309(29 ; 7)$ & $v(\mathrm{C}=\mathrm{C})_{\text {ring } 1}+\gamma(\mathrm{CH})$ \\
\hline 1304 & 1306 & $1292(223 ; 20)$ & $1292(217 ; 20)$ & $\delta(\mathrm{CH})_{\text {ring1 }}+v\left(\mathrm{C}-\mathrm{CF}_{3}\right)$ \\
\hline 1260 & 1265 & $1277(11 ; 7)$ & $1275(9 ; 12)$ & $\mathrm{t}\left(\mathrm{CH}_{2}\right)$ \\
\hline 1244 & 1246 & $1213(350 ; 20)$ & $1212(334 ; 19)$ & $\omega\left(\mathrm{CH}_{2}\right)+\mathrm{t}\left(\mathrm{CH}_{2}\right)+v(\mathrm{C}-\mathrm{O})$ \\
\hline 906 & 890 & $901(5 ; 1)$ & $901(5 ; 1)$ & $\gamma(\mathrm{CH})_{\text {ring }}$ \\
\hline 848 & 851 & $825(10 ; 17)$ & $839(6 ; 12)$ & $\mathrm{r}\left(\mathrm{CH}_{2}\right)+\mathrm{t}\left(\mathrm{CH}_{2}\right)$ \\
\hline 819 & 819 & $805(15 ; 6)$ & $808(23 ; 17)$ & $\mathrm{r}\left(\mathrm{CH}_{2}\right)+\gamma(\mathrm{CH})_{\text {ring }}$ \\
\hline \multirow[t]{2}{*}{782} & 783 & $777(6 ; 10)$ & & $\mathrm{r}\left(\mathrm{CH}_{2}\right)+\mathrm{r}\left(\mathrm{NH}_{2}\right)$ \\
\hline & 747 & & $754(2 ; 11)$ & $\mathrm{r}\left(\mathrm{CH}_{2}\right)+\mathrm{r}\left(\mathrm{ND}_{2}\right)$ \\
\hline 732 & 733 & $717(1 ; 1)$ & $717(1 ; 1)$ & $\delta_{\mathrm{s}}\left(\mathrm{CF}_{3}\right)+\mathrm{r}\left(\mathrm{CH}_{2}\right)$ \\
\hline 650 & 653 & $691(29 ; 1)$ & $691(29 ; 1)$ & $\gamma(\mathrm{CH})_{\text {ring }}$ \\
\hline 638 & 639 & $632(17 ; 5)$ & $632(16 ; 5)$ & $v(\mathrm{C}=\mathrm{C})_{\text {ring } 1}$ \\
\hline 622 & 622 & $607(1 ; 4)$ & $611(7 ; 3)$ & $v(\mathrm{C}=\mathrm{C})_{\text {ring } 2}+\Gamma(\mathrm{COC})$ \\
\hline 411 & 415 & $408(0 ; 1)$ & $409(2 ; 3)$ & $\Gamma(\mathrm{CCC})+\Gamma(\mathrm{CNC})+\Gamma(\mathrm{COC})$ \\
\hline 361 & 348 & $333(1 ; 3)$ & $330(1 ; 3)$ & $\Delta(\mathrm{CCC})+\Delta(\mathrm{CNC})+\Delta(\mathrm{COC})$ \\
\hline 291 & 297 & $305(4 ; 1)$ & $304(4 ; 1)$ & $\Gamma(\mathrm{CCC})+\Gamma(\mathrm{CNC})+\Gamma(\mathrm{COC})$ \\
\hline 257 & 259 & $253(6 ; 5)$ & $251(8 ; 6)$ & $\Gamma(\mathrm{CCC})+\Gamma(\mathrm{CNC})+\Gamma(\mathrm{COC})$ \\
\hline 215 & 208 & $218(2 ; 1)$ & $207(2 ; 2)$ & $\tau\left(\mathrm{CH}_{3}\right)$ \\
\hline 192 & 194 & $184(2 ; 4)$ & $184(2 ; 3)$ & skeletal mode \\
\hline \multirow[t]{2}{*}{171} & 174 & $157(3 ; 1)$ & $156(3 ; 1)$ & skeletal mode \\
\hline & & $17(1 ; 1)$ & $16(1 ; 1)$ & $\tau\left(\mathrm{CF}_{3}\right)$ \\
\hline
\end{tabular}

${ }^{a}$ Experimental values obtained for fluoxetine $R / S$ racemic mixture. ${ }^{b}$ Wavenumbers above $400 \mathrm{~cm}^{-1}$ are scaled by a factor of $0.9614^{18}$ (IR intensities in $\mathrm{km} \mathrm{mol}^{-1}$; Raman scattering activities in $\AA \mathrm{amu}^{-1}$ ). ${ }^{c} v_{\mathrm{s}}$ and $v_{\mathrm{as}}$, stretching (symmetric or antissymetric, respectively); $\delta$, in-plane deformation; t, twisting; r, rocking; $\omega$, wagging; sciss., scissoring; $\gamma$, out-of-plane deformation; $\Delta$, in-plane deformation of skeleton atoms; $\Gamma$, out-of-plane deformation of skeleton atoms.

enantiomer. As the conformational preferences were not stereodependent (Figure 5A, isomers $S$ and $R$ ), the subsequent investigation was performed for only one enantiomer. Accordingly, a full geometry optimization was then performed for fluoxetine both in the base and in the salt form. Three distinct conformations were obtained for the neutral molecule: I, II, and
III (Figure 5A), with relative populations at room temperature equal to $47.7 \%, 43.2 \%$, and $9.1 \%$, respectively, while only one was found for the N-protonated form (Figure 5B). Geometries I and II interconvert through nitrogen rotation, thus differing in the orientation of the $\mathrm{N}-\mathrm{H}$ bond. As for conformer III, it displays a skewed conformation of the methylpropylamine 

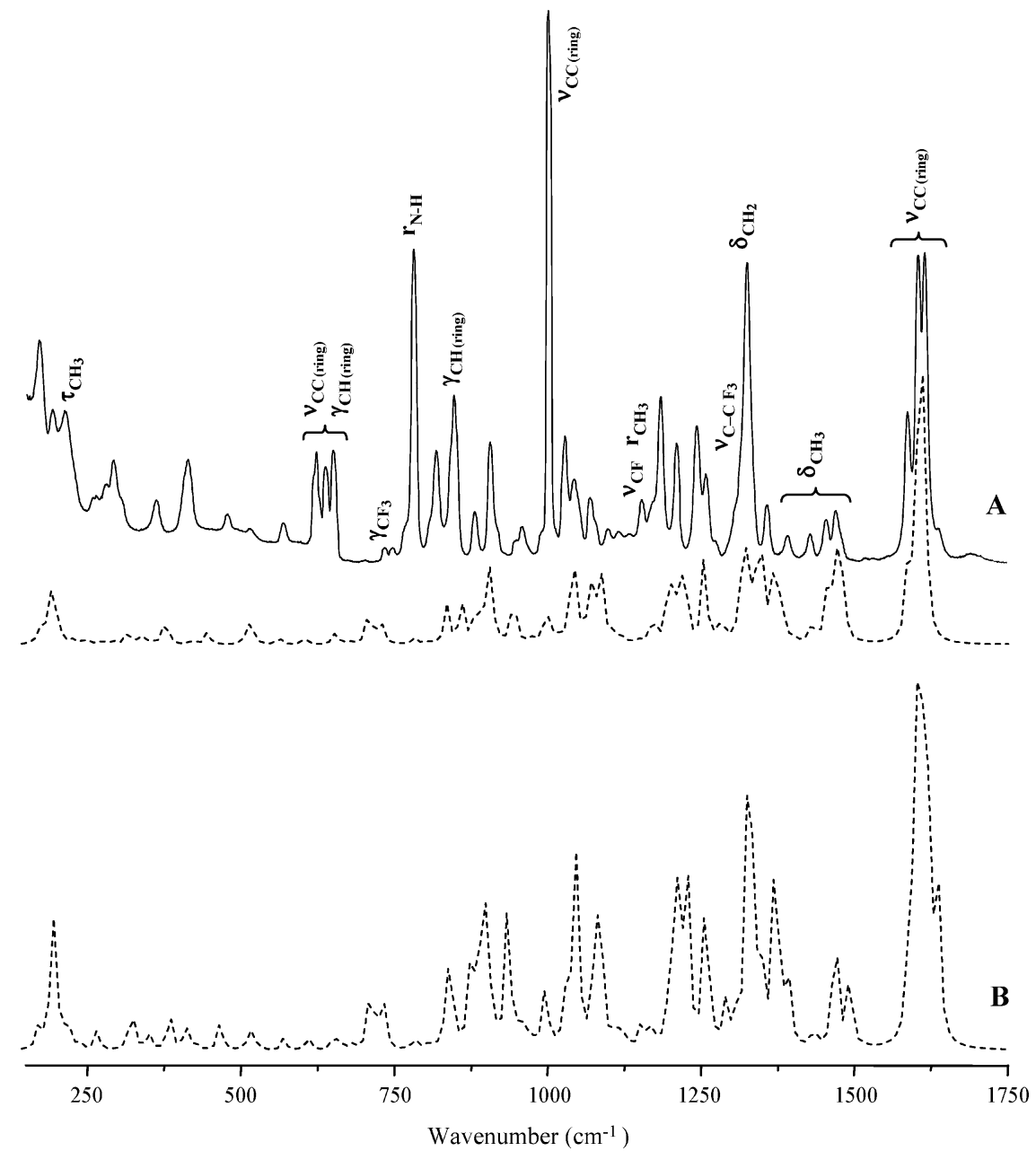

Figure 8. Experimental and calculated Raman spectra $\left(125-1750 \mathrm{~cm}^{-1}\right.$, solid state, $\left.25{ }^{\circ} \mathrm{C}\right)$ for N-protonated fluoxetine (A) and N-protonated norfluoxetine (B) (solid line, experimental; dotted line, calculated (B3LYP/6-31G**)).

group, ${ }^{12} \mathrm{CH}_{3}$ and ${ }^{2} \mathrm{CH}_{2}$ being eclipsed $\left(\left(\mathrm{C}_{12} \mathrm{~N}_{11} \mathrm{C}_{1} \mathrm{C}_{2}\right)=0^{\circ}\right)$ as compared to the conformational preferences presented in I and II $\left(\left(\mathrm{C}_{12} \mathrm{~N}_{11} \mathrm{C}_{1} \mathrm{C}_{2}\right)\right.$ ca. $\left.180^{\circ}\right)$.

N-Protonated fluoxetine (Figure 5B) displays particular conformational features, which correspond to a minimization of the torsional strain within the molecule: (i) the two aromatic rings are skewed relative to each other, in an almost perpendicular relative position $\left(\left(\mathrm{C}_{13} \mathrm{C}_{3} \mathrm{O}_{4} \mathrm{C}_{5}\right)=-75.8^{\circ},\left(\mathrm{C}_{3} \mathrm{O}_{4} \mathrm{C}_{5} \mathrm{C}_{6}\right)\right.$ $=4.4^{\circ},\left(\mathrm{C}_{3} \mathrm{O}_{4} \mathrm{C}_{5}\right)=119.9^{\circ}$, Figure 6), thus hindering any intramolecular ring-ring stacking interactions, as shown by the following distances: $d\left(\mathrm{C}_{6} \cdots \mathrm{C}_{18}\right)=392.7 \mathrm{pm}, d\left(\mathrm{H}_{6} \cdots \mathrm{H}_{3}\right)=$ $224.2 \mathrm{pm}$, and $d\left(\mathrm{H}_{6} \cdots \mathrm{H}_{18}\right)=309.9 \mathrm{pm}$ (Table 1); (ii) to minimize torsional and steric strains, $\mathrm{N}$-methylpropanamine side chain adopts a staggered $(\mathrm{C} 1-\mathrm{C} 2$ bond) and an antiperiplanar (between $\mathrm{N}_{11}$ and $\mathrm{C} 3$; $\left.\left(\mathrm{N}_{11} \mathrm{C}_{1} \mathrm{C}_{2} \mathrm{C}_{3}\right)=175.9^{\circ}\right)$ relationship and is folded toward the phenoxy moiety $\left(\left(\mathrm{C}_{1} \mathrm{C}_{2} \mathrm{C}_{3} \mathrm{O}_{4}\right)=-56.4^{\circ}\right.$, Figure 6).

The geometrical parameters presently calculated for fluoxetine hydrochloride agree well with the X-ray data previously reported for this system (Table 1). ${ }^{31}$

The same procedure was undertaken for norfluoxetine hydrochloride, for which only one geometry for each protonation state $(q=0$ and $q=+1)$ was found to occur at room temperature (Figure 5C). Despite demethylation, this molecule displays some conformational preferences identical to protonated fluoxetine $\left(\left(\mathrm{N}_{11} \mathrm{C}_{1} \mathrm{C}_{2} \mathrm{C}_{3}\right)=175.4^{\circ},\left(\mathrm{C}_{1} \mathrm{C}_{2} \mathrm{C}_{3} \mathrm{O}_{4}\right)=-55.9^{\circ}\right.$, $\left(\mathrm{C}_{13} \mathrm{C}_{3} \mathrm{O}_{4} \mathrm{C}_{5}\right)=-75.7^{\circ}$, and $\left(\mathrm{C}_{3} \mathrm{O}_{4} \mathrm{C}_{5}\right)=119.9^{\circ}$, Figure $\left.5 \mathrm{C}\right)$, except for the (trifluoromethyl)phenoxypropanamine moiety
$\left(\left(\mathrm{C}_{2} \mathrm{C}_{3} \mathrm{O}_{4} \mathrm{C}_{5}\right)=159^{\circ},\left(\mathrm{C}_{1} \mathrm{C}_{2} \mathrm{C}_{3} \mathrm{O}_{4}\right)=-62.0^{\circ}\right.$, and $\left(\mathrm{C}_{3} \mathrm{O}_{4} \mathrm{C}_{5} \mathrm{C}_{6}\right)$ $=3.3^{\circ}$ vs $161^{\circ}$ and $-56.4^{\circ}, 4.4^{\circ}$, respectively, for fluoxetine (Figure 5)). These conformational differences may be responsible for the distinct electrochemical behavior presently detected for norfluoxetine, as compared to fluoxetine, because they markedly influence the transmission of inductive and mesomeric effects along the molecular system.

Spectroscopic Studies. Figure 7 represents the experimental Raman solid-state pattern, in the $2000-3500 \mathrm{~cm}^{-1}$ region, for hydrochloride fluoxetine racemic mixture, both undeuterated (Figure 7A) and deuterated (Figure 7B). As the harmonic vibrational frequencies were calculated for each fluoxetine stable conformer, it was possible to acquire the theoretical vibrational spectra of the compound as well as the complete assignment of its experimental Raman bands (Figure 7A, Table 2).

The most characteristic Raman bands detected for solid hydrochloride fluoxetine may then be grouped as follows (Figures 7A and 8A, Table 2): (i) NH vibrations, stretching modes at 2969 and $2829 \mathrm{~cm}^{-1}$, and deformations at 850-650 $\mathrm{cm}^{-1}$; (ii) ring modes, apart from a typical set of three signals between 655 and $622 \mathrm{~cm}^{-1}$, the most intense ring $v_{\mathrm{CC}}$ are centered at 1617, 1605, and $1010 \mathrm{~cm}^{-1}$; (iii) $\mathrm{CH}_{3}$ modes, stretching vibrations, as intense bands from ca. 2940 to 2820 , and deformations yielding quite low signals between ca. 1390 and $1470 \mathrm{~cm}^{-1}, 1143 / 959 \mathrm{~cm}^{-1}$ (rocking), and $257 \mathrm{~cm}^{-1}$ (torsion); (iv) $\mathrm{CF}_{3}$ modes (giving rise to weak Raman bands), $-\mathrm{C}-\mathrm{CF}_{3}$ and $\mathrm{C}-\mathrm{F}$ stretchings at 1304 and $1133 \mathrm{~cm}^{-1}$ (respectively), and $\mathrm{CF}_{3}$ out-of-plane deformation at ca. $730 \mathrm{~cm}^{-1}$. 
To better understand the spectroscopic data, the Raman spectra of the N-deuterated fluoxetine were also obtained. The Raman pattern of the deuterated drug comprises two $v_{\mathrm{ND}}$ bands corresponding to the $\mathrm{ND}_{2}$ group (Figure $7 \mathrm{~B}$, Table 2). Actually, the increase in mass of the ND oscillator relative to $\mathrm{NH}$ allows one to uncover the corresponding stretching modes, which suffer a large shift to lower wavenumbers, from 2969/2829 to 2220 / $2138 \mathrm{~cm}^{-1}$. Consequently, the difference spectrum between the undeuterated and deuterated samples (Figure 7C) leads to a clear identification of the two $v_{\mathrm{NH}}$ modes, otherwise mixed with the intense $v_{\mathrm{CH}}$ vibrations. This enables a rapid and unequivocal identification of hydrochloride fluoxetine in a pharmacological formulation, because it easily allows one to distinguish it from the excipients or any other compounds present in the solid mixture.

Apart from the expected downward shift of the NH stretching modes, fluoxetine deuteration is responsible for some changes in the vibrations of the terminal methyl group (adjacent to the deuterated amine), a blue shift of the symmetric deformation (from 1393 to $1402 \mathrm{~cm}^{-1}$ ), and a red shift of the rocking and torsion modes (from 1133 to $1118 \mathrm{~cm}^{-1}$ and 218 to $207 \mathrm{~cm}^{-1}$, respectively, Table 2). The amine scissoring vibration was also found to be drastically affected by $\mathrm{N}$-deuteration, $\delta_{\mathrm{NH}}=1603$ $\mathrm{cm}^{-1}$ versus $\delta_{\mathrm{ND}}=1171 \mathrm{~cm}^{-1}$, as predicted by the calculations (Table 2).

Comparison between the Raman experimental data collected for fluoxetine hydrochloride and the corresponding calculated frequencies (after scaling according to Scott and Radom ${ }^{18}$ ) evidences a quite good overall agreement (Figure 8, Table 2). Actually, the main discrepancies between experimental and theoretical wavenumbers were detected for those vibrational modes that are most affected by intermolecular hydrogen bonds, ${ }^{32}$ not considered in the theoretical approach presently used, such as H-type interactions. These close contacts, mainly involving the $N$-methyl amine group, are clearly reflected in the Raman spectra through the large shifts of the $v_{\mathrm{NH}}$ and $v_{\mathrm{ND}}$ modes to lower wavenumbers as compared to the calculated values (for the isolated molecule): $\nu_{\mathrm{NH}}(\exp )=2969 / 2829 \mathrm{~cm}^{-1}$ versus $v_{\mathrm{NH}}($ calc $)=3343 / 3290 \mathrm{~cm}^{-1}$, and $v_{\mathrm{ND}}(\exp )=2220 / 2138$ $\mathrm{cm}^{-1}$ versus $\nu_{\mathrm{ND}}($ calc $)=2467 / 2385$ (Table 2$)$. This deviation is less noticeable for the deuterated amine stretching vibrations, because the $(\mathrm{N}) \mathrm{D} \cdots \mathrm{N}(\mathrm{D})$ close contacts are not as strong as the $(\mathrm{N}) \mathrm{H} \cdot \cdots \mathrm{N}(\mathrm{H})$ ones.

The vibrational data presently obtained also enable one to distinguish fluoxetine from its main metabolite, norfluoxetine (Figure 8). In fact, while the former gives rise to characteristic bands ascribed to the methyl group, $\delta_{\mathrm{CH} 3}$ (from 1390 to 1470 $\mathrm{cm}^{-1}$ ), $\mathrm{r}_{\mathrm{CH} 3}$ (at $1167 \mathrm{~cm}^{-1}$ ), and $\tau_{\mathrm{CH} 3}\left(\right.$ at $215 \mathrm{~cm}^{-1}$ ) (Table 2 ), these are absent in the spectrum of norfluoxetine, which comprises typical $\mathrm{NH}_{3}$ vibrations instead, such as deformation modes (between 900 and $1400 \mathrm{~cm}^{-1}$ ) and $\tau_{\mathrm{NH} 3}\left(\right.$ at $218 \mathrm{~cm}^{-1}$ ). Moreover, the two fluoxetine $\mathrm{NH}_{2}$ stretching vibrations, observed at $2969\left(\nu_{\mathrm{as}}\right)$ and $2829 \mathrm{~cm}^{-1}\left(\nu_{\mathrm{s}}\right)$, are substituted by three $v_{\mathrm{NH} 3}$ modes (two asymmetric and one symmetric), around $3000 \mathrm{~cm}^{-1}$.

\section{Conclusions}

The well-known antidepressant drug fluoxetine and its metabolite norfluoxetine were studied as to their electrochemical behavior and their structural preferences.

The syntheses and study of the electrochemical behavior of two fluoxetine analogues, 1-(benzyloxy)-4-(trifluoromethyl)benzene and $N$-methyl-3-phenylpropan-1-amine hydrochloride, enabled us to conclude that the main oxidative processes occurring in fluoxetine are related to the oxidation of the secondary amine group and an oxidation occurring at the aromatic nucleus, yielding an unstable cation-radical that could undergo further subsequent reactions such as dimerization.

The conformational analysis carried out for both the protonated and the unprotonated states of the molecules, as well as for their N-deuterated forms, allowed us to detect conformational differences between the drug and its metabolite that could explain the distinct electrochemical behavior presently detected for norfluoxetine, as compared to fluoxetine. The predicted vibrational spectra for the most stable calculated conformers of the systems lead to a complete assignment of the corresponding experimental Raman pattern. The characteristic amine stretching modes were unequivocally identified, enabling us to clearly distinguish fluoxetine and norfluoxetine by analysis of this spectral region.

The results gathered along this work are a valid contribution to the study and clarification of the effects of $\mathrm{pH}$ on bioaccumulation, metabolism, and toxicity of the pharmaceutical drug. Moreover, the present study evidences the motive for the reduced use of electroanalytical methods for fluoxetine quantification and points out the utility of Raman spectroscopy as a high sensitivity and noninvasive technique for a rapid and reliable characterization of samples.

Acknowledgment. We thank Lilly Farma (Lisbon, Portugal) who kindly provided fluoxetine and norfluoxetine standards.

\section{References and Notes}

(1) Hiemke, C.; Härtter, S. Pharmacol. Ther. 2000, 85, 11.

(2) El-dawy, M. A.; Mabrouk, M. M.; El-Barbary, F. A. J. Pharm. Biomed. Anal. 2002, 30, 561.

(3) Lajeunesse, A.; Gagnon, C.; Sauve, S. Anal. Chem. 2008, 80, 5325.

(4) Ternes, T. A. Water Res. 1998, 32, 3245.

(5) Kolpin, D. W.; Furlong, E. T.; Meyer, M. T.; Thurman, E. M.; Zaugg, S. D.; Barber, L. B.; Buxton, H. T. Environ. Sci. Technol. 2002, 36, 1202.

(6) Fong, P. P. In Pharmaceuticals and Personal Health Care Products in the Environment: Scientific and Regulatory Issues; Daughton, C. G., Jones-Lepp, T. L., Eds.; ACS Symposium Series 791; American Chemical Society: Washington, DC, 2001; pp 264-281.

(7) Brooks, B. W.; Chambliss, C. K.; Stanley, J. K.; Ramirez, A.; Banks, K. E.; Johnson, R. D.; Lewis, R. J. Environ. Toxicol. Chem. 2005, 24,464 .

(8) Nakamura, Y.; Yamamoto, H.; Sekizawa, J.; Kondo, T.; Hirai, N.; Tatarazako, N. Chemosphere 2008, 70, 865.

(9) Fent, K.; Looser, P. W. Water Res. 1995, 29, 1631.

(10) Looser, P. W.; Bertschi, S.; Fent, K. Appl. Organomet. Chem. 1998, 12,601 .

(11) Frisch, M. J.; Gaussian 03, revision B.04; Gaussian, Inc.: Pittsburgh, PA, 2003.

(12) Lee, C.; Yang, W.; Parr, R. G. Phys. Rev. B 1988, 37, 785.

(13) Miehlich, B.; Savin, A.; Stoll, H.; Preuss, H. Chem. Phys. Lett. $1989,157,200$.

(14) Becke, A. Phys. Rev. A 1988, 38, 3098.

(15) Becke, A. J. J. Chem. Phys. 1993, 98, 5648.

(16) Petersson, G. A.; Bennett, A.; Tensfeldt, T. G.; Al-Laham, M. A.; Shirley, W. A.; Mantzaris, J. J. Chem. Phys. 1988, 89, 2193.

(17) Peng, C.; Ayala, P. Y.; Schlegel, H. B.; Frisch, M. J. Comput. Chem. 1996, $17,49$.

(18) Scott, A. P.; Radom, L. J. Phys. Chem. 1996, 100, 16502.

(19) Milhazes, N.; Cunha-Oliveira, T.; Martins, P.; Garrido, J.; Oliveira, C.; Rego, A. C.; Borges, F. Chem. Res. Toxicol. 2006, 19, 1294.

(20) Hammarberg, E.; Nordvall, G.; Leideborg, R.; Nylöf, M.; Hanson, S.; Johansson, L.; Thorberg, S.-O.; Tolf, B.-R.; Jerning, E.; Svantesson, G. T.; Mohell, N.; Ahlgren, C.; Westlind-Danielsson, A.; Csöregh, I.; Johansson, R. J. Med. Chem. 2000, 43, 2837.

(21) Abdel-Magid, A. F.; Carson, K. G.; Harris, B. D.; Maryanoff, C. A.; Shah, R. D. J. Org. Chem. 1996, 61, 3849.

(22) Garrido, J. M. P. J.; Delerue-Matos, C.; Borges, F.; Macedo, T. R. A.; Oliveira-Brett, A. M. Electroanalysis 2004, 16, 1497.

(23) Milhazes, N.; Martins, P.; Uriarte, E.; Garrido, J.; Calheiros, R.; Marques, M. P. M.; Borges, F. Anal. Chim. Acta 2007, 596, 231. 
(24) Coomber, D. C.; Tucker, D. J.; Bond, A. M. Anal. Chem. 1997, 69,898 .

(25) Said, A. H.; Mhalla, F. M.; Amatore, C.; Verpeaux, J.-N. J. Electroanal. Chem. 1999, 464, 85.

(26) Garrido, J. M. P. J.; Matos, C. D.; Borges, F.; Macedo, T. R. A.; Oliveira-Brett, A. M. Electroanalysis 2004, 16, 1427.

(27) Garrido, E. M. P. J.; Garrido, J. M. P. J.; Esteves, M.; SantosSilva, A.; Marques, M. P. M.; Borges, F. Electroanalysis 2008, 20, 1454. (28) Roque da Silva, A. M. S.; Lima, J. C.; Teles, M. T. O.; Oliveira Brett, A. M. Talanta 1999, 49, 611.
(29) Lencastre, R. P.; Matos, C. D.; Garrido, J.; Borges, F.; Garrido, E. M. J. Food Drug Anal. 2006, 14, 242.

(30) Masui, M.; Sayo, H.; Tsuda, Y. J. Chem. Soc. B 1968, 973.

(31) Robertson, D. W.; Jones, N. D.; Swartzendruber, J. K.; Yang, K. S.; Wong, D. T. J. Med. Chem. 1988, 31, 185.

(32) Steiner, T. Angew. Chem., Int. Ed. 2002, 41, 48, and references therein.

JP904306B 